\title{
The Pharmacological management of Depression - Update 2017
}

\author{
Elzbieta Osuch, ${ }^{1}$ Andre Marais ${ }^{2 *}$ \\ 'Department of Pharmacology \& Therapeutics, School of Medicine, Sefako Makgatho Health Sciences University, South Africa \\ ${ }^{2}$ Department of Pharmacology, School of Medicine, Faculty of Health Sciences, University of Pretoria, South Africa \\ *Corresponding author, email:dramarais@gmail.com / andre.marais@up.ac.za
}

\begin{abstract}
Depression affects nearly 350 million people worldwide. Local data indicates that approximately $17 \%$ of all South Africans will experience at least one episode of depression in their lifetime. Depressive disorders contribute significantly towards overall morbidity and increased risk for suicide. Antidepressant therapy remains one of the cornerstones in the management of depressive disorders. Although the efficacy of antidepressive drugs is continuously subjected to criticism, thousands of controlled clinical trials have shown, and will continue to show, their benefit in the effective treatment of depressive disorders. Since the introduction of antidepressants in the early 1950s, researchers have been searching for an ideal antidepressant able to adequately reduce, preserve and prevent features of depression with the absence of side effects. This article summarizes the currently available antidepressant drugs in South Africa. Discontinued products have been omitted and newly registered agents have been added. This review does not contain reference to any experimental drug, or substances not yet available for local use.
\end{abstract}

Keywords: Major depressive disorder, antidepressant, serotonin, noradrenaline, dopamine

\section{Introduction}

It is estimated that $\mathbf{3 5 0}$ million people worldwide suffer from depression, and predictions indicate that by the year 2020 Major Depressive Disorder (MDD) will be the second largest contributor to the global burden of disease, only being surpassed by heart disease. ${ }^{1}$ Depression affects approximately one in 15 adults (6.7\%), whereby one in six individuals (16.6\%) will experience at least one life time episode. ${ }^{2}$ More than 800000 people commit suicide each year and it is estimated that about $50 \%$ of depressed patients have a history of at least one suicide attempt during their lifetime. Suicide is the second leading cause of death in the age group 15-29 years. ${ }^{3}$ Limited data regarding the epidemiology of MDD in South Africa is available, however studies conducted from 2008 to 2012, showed a $41 \%$ increase in the incidence of mental disorders. From these disorders, MDD was shown to have a 12 month prevalence of $16.5 \%$ and a lifetime prevalence of $30.3 \%{ }^{4}$ Research done by the Faculty of Mental Health at the University of Cape Town shows that nearly three quarters of South Africans diagnosed with mental illness are not receiving treatment, and that $11 \%$ of all non-natural deaths in South Africa are the result of suicide. ${ }^{5}$

\section{Clinical characteristics of depressive disorders}

MDD is usually associated with severe and persistent symptoms leading to impairment in psychosocial functioning and increased mortality. Symptoms of depression may include fatigue, anhedonia, restlessness, subjectively depressed mood, psychomotor retardation, cognitive impairment, weight and appetite changes, sleep disturbances, feelings of guilt and worthlessness and thoughts of death or suicide. Depressive symptoms must be present for a period of at least two weeks in order to make a clinical diagnosis. ${ }^{6}$ Depressive episodes differ in the number and severity of symptoms, and are categorized as mild, moderate, or severe. MDD is typically a recurrent disorder with an estimated relapse rate of approximately $50-85 \% .^{7}$ The history of manic episodes being present or absent in a depressed patient is important, since different treatment approaches need to be considered. Bipolar affective disorder consists of manic and depressive episodes which are intermittently separated by periods of normal mood. Manic episodes embroil the presence of elevated or irritable mood, over-activity, inflated self-esteem and a decreased need for sleep. Both MDD and bipolar disorder may become chronic if untreated. ${ }^{8}$

\section{Pathophysiology of depression}

Depression is clinically and etiologically a heterogenic disease, although the exact pathophysiology still remains largely elusive. Theories have suggested that the disorder may be the result of a complex interaction between social, psychological and biological factors. These include genetic factors, psychosocial stress and stress hormones, neurotransmitter imbalance, and changes in the circadian rhythm. Different theories regarding the pathophysiological cause, including the considerable variation in symptoms and disease progression in individual 
patients presenting with the disorder, have resulted in the absence of a singular unified hypothesis for depression. ${ }^{9}$ As a result, antidepressant treatment, including psychological and biological approaches, should be individualized for each patient. Notwithstanding this approach, the high rate of treatment failure remains a serious concern. ${ }^{10}$

Genetic factors are responsible for $30-40 \%$ of patients being susceptible to MDD. ${ }^{11}$ Literature provides consistent evidence on the relation in volume loss of the hippocampus and other brain regions, and the duration of depressive symptoms. ${ }^{12}$ Glucocorticoid neurotoxicity, glutamatergic toxicity, decreased neurotrophic factors, and decreased neurogenesis have additionally been proposed as possible mechanisms explaining brain volume loss in depressed patients. ${ }^{13,14}$ This suggests that untreated depressive disorders result in hippocampal volume loss, increased stress sensitivity and an upsurge in the risk of recurrence. $^{15}$

\section{Altered stress hormone secretion is more prominent in depressed individuals with a history of childhood trauma. ${ }^{16}$ In addition, the physiological response to stress has been shown to be partly gender-specific. Females have a superior stress responsiveness compared to their male counterparts, which is consistent with the higher incidence of MDD in women. ${ }^{14,17}$ Hypercortisolemia with elevated cerebrospinal fluid levels of Corticotropin- Releasing Hormone ( $\mathrm{CRH}$ ) have furthermore been found present in patients with severe and psychotic depression. ${ }^{18}$ Cytokines such as interleukin-1 $a$, tumor necrosis factor-a, and interleukin-6, emanating via the release of glucocorticoids, activate the hypothalamic-pituitary adrenal (HPA) axis. ${ }^{19}$ HPA axis activation in turn causes an inflammatory response which may lead to impairment of the central serotonin system, thereby resulting in symptoms of depression. ${ }^{20}$ Despite this well documented association, pharmacological modulation of the HPA axis as antidepressant therapy has been dismal.}

Monoamine-deficiency and depletion of central nervous system (CNS) neurotransmitters (serotonin, noradrenaline and dopamine) has proved to be the most clinically relevant neurobiological theory in the pathophysiology of depression. Drugs which inhibit monoamine reuptake, thereby causing an elevated concentration in the synaptic cleft, are well known for their clinical effectiveness as antidepressant therapy. ${ }^{21}$ Abnormalities in relative serotonin levels, and especially the serotonin-1A (5HT-1A) receptor responsible for regulating serotonin function, has been implicated as a major cause of depression. Decreased expression of this receptor has been found in multiple brain areas of patients with MDD. ${ }^{22}$ An increased presence of the central monoamine oxidase enzymes (MAO) responsible for the breakdown of serotonin will cause serotonin deficiency, thereby culminating in depression. ${ }^{23}$ In addition, loss-of-function mutations in the gene coding for the brain-specific enzyme tryptophan hydroxylase- 2 may explain the loss of serotonin production as a rare risk factor for depression. ${ }^{24}$ Dysfunction of the central noradrenergic and dopaminergic systems is furthermore responsible for the pathophysiology in
MDD. Here, a reduction in the total concentration of gammaaminobutyric acid (GABA) in the prefrontal and occipital cortex, together with a debilitated glutamate neurotransmitter system may cause depressive symptoms. In addition, episodes of chronic stress reduce GABA-A receptor function, possibly through changes in neuroactive steroid synthesis. ${ }^{25,26}$

\section{Treatment goals}

All other medical conditions responsible for depressive symptoms have to be excluded before a diagnosis of depressive disorder should be made. A wide range of effective multidisciplinary treatment is available for MDD. These include pharmacotherapy and psychotherapy (e.g. cognitive-behavioral therapy, interpersonal therapy). The choice of treatment should be individualized and based on a meticulous diagnostic assessment of symptoms (physical examination and laboratory investigations), comorbid psychiatric conditions (mental status, psychoactive substance abuse and suicide risk), general medical conditions (thyroid disease, cardiovascular disease, dementia, stroke, and metabolic syndrome), treatment history, social history, occupational history and family history.

Each phase in the successful treatment of depression has a different aim, and requires a favorable "response", which is generally measured by a $50 \%$ reduction in the patient's depression score. ${ }^{27}$ Ultimately the aim is to achieve full remission and the elimination of depressive symptoms with depression scores within the normal range.

- Acute phase - Treatment should induce remission of all symptoms

- Continuation phase - Treatment should preserve remission

- Maintenance phase-Treatment should prevent the recurrence of subsequent major depressive episodes

\section{Pharmacological options}

In addition to psychotherapeutic treatment, various pharmacological agents are available in the management of depression. Some of the newer drugs have not achieved South African registration yet, and are therefore not included in this summary. The currently available drugs are listed in Table I below. These include selective serotonin reuptake inhibitors (SSRIs), tricyclic antidepressants (TCAs), monoamine oxidase inhibitors (MAOIs), serotonin-noradrenaline reuptake inhibitors (SNRIs), and atypical antidepressants. Atypical antidepressants are further classified as dopamine reuptake inhibitors (DRIs), tetracyclic antidepressants, serotonin receptor antagonists and reuptake inhibitors (SARIs), selective noradrenaline reuptake inhibitors (NTIs), multimodal antidepressants, melatonergic agonists, and various herbal and complementary medicines (eg. St. John's wort). As a rule, monotherapy with benzodiazepines are not recommended, and are only indicated as short-term adjunctive therapy in the initial symptomatic management of anxiety, insomnia, and agitation. Benzodiazepines should be avoided in depressed patients with comorbid substance-abuse disorders. ${ }^{28}$ 
The choice of drug should primarily be guided by the safety and tolerability profile, contraindications, history and response to previous treatment, and patient compliance. Cost and product availability should be considered and may contribute to treatment failure. Other factors responsible for treatment failure include medication non-compliance, inadequate duration of therapy, inadequate dosing and misdiagnosis. For a clinical response to become evident, it is necessary to continue treatment for 2-12 weeks at a therapeutic dose. Treatment for MDD should be altered if the patient does not have an adequate pharmacotherapeutic response within 6-8 weeks. Patients presenting with a first episode of MDD in the absence of suicidal risk require treatment for at least 4-9 months after a satisfactory response has been achieved. In patients with a history of two or more depressive episodes, a longer course of maintenance treatment may prove beneficial. ${ }^{29}$

\section{Selective serotonin reuptake inhibitors (SSRIs)}

SSRIs are some of the most widely prescribed groups of drugs worldwide. At the time of writing this report, 55 individual generic and originator SSRI products were available for prescription by South African doctors. These include citalopram, escitalopram, fluoxetine, paroxetine, fluvoxamine and sertraline. All SSRIs share a similar mechanism of action and general receptor mediated side effect profile. Individual compounds however differ in their pharmacokinetic and pharmacodynamic properties, resulting in varying efficacies. The pharmacological effect is achieved by selectively blocking serotonin reuptake at the presynaptic neurons, thereby increasing the concentration of serotonin in the synaptic cleft. Pure SSRIs have negligible selectivity for other monoamine transporters, thus thwarting side effects associated with activity at muscarinic, $a^{-}$adrenergic and histaminic receptors. Common adverse effects include gastrointestinal upset (nausea, decreased appetite, diarrhoea, and dry mouth), CNS effects (insomnia, sedation, dizziness, and headache), sexual dysfunction, weight gain, anhedonia and fatigue..$^{30}$

SSRIs are metabolized by the liver cytochrome P450 enzyme system and may therefore inhibit the metabolism of various other drugs making use of this pathway - resulting in toxic plasma concentrations of those substances. In addition, the combination of SSRIs with other serotonergic agents may result in the Serotonin Syndrome, which is marked by agitation, confusion, sweating, pupil dilatation and hyperthermia. Complications include seizures and muscle rhabdomyolysis. Most SSRIs display a high rate of plasma protein binding, which can lead to increased therapeutic or toxic effects of other protein-bound medications. Except for citalopram, SSRIs are unproblematic in patients with cardiac disease. These side effects are less prominent compared to other antidepressive agents, therefore ensuring treatment preference. Based on the convenient dosing profile and low incidence of toxicity, SSRIs are the first line of treatment for acute MDD, including late onset depression. ${ }^{31}$ All SSRIs have an increased risk of suicide, especially in children and adolescents. Administering a SSRI however remains the first line treatment. The suicidal risk should be balanced against clinical benefits and close monitoring should be in place. ${ }^{28}$
Citalopram and escitalopram appears to be the best tolerated, followed by fluoxetine, sertraline, paroxetine and fluvoxamine.

\section{Tricyclic antidepressants (TCAs)}

Currently available TCAs in South Africa include amitriptyline, imipramine, clomipramine, dothiepin and trimipramine. TCAs have a longstanding record in the effective management of depressive disorders with anxiety or somatic manifestations. These agents principally block noradrenaline and serotonin reuptake. In addition they also block serotonergic, histaminic, aadrenergic and muscarinic receptors. Recently their usefulness has declined as a result of the unfavorable side-effect profile and considerable toxicity in overdose. The adverse effects of TCAs are related to its anticholinergic and antihistaminic properties. Common side effects include sedation, dizziness, hypotension, blurred vision, confusion, dry mouth, constipation, urinary retention, sexual dysfunction and weight gain. Caution should be taken when treating patients with cardiac conduction abnormalities, since tricyclic antidepressants may prolong the QT interval, thereby causing ventricular dysrhythmia and increase mortality. TCAs have a narrow therapeutic index, where a dose of approximately six times the upper limit may prove fatal. The use of these agents are therefore reserved as an alternative for depressed patients not responding to first line treatment with a SSRI. ${ }^{32}$ TCAs are substrates for the CYP2D6 and CYP1A2 hepatic isoenzymes, and their effect may therefore be potentiated by other inhibitors or substrates requiring these cytochromes (e.g. quinidine, cimetidine, SSRIs, and ritonavir) for metabolism. Combination use with other serotonergic agents will result in the Serotonin Syndrome as described above.

\section{Monoamine oxidase inhibitors (MAOIs)}

MAOIs include moclobemide (reversible), and tranylcypromine (irreversible). MAOls inhibit the monoamine oxidase enzyme responsible for the breakdown of catecholamines in the synaptic cleft. Inactivation of the monoamine oxidase enzymes therefore increases the available concentration of noradrenaline, serotonin and dopamine. These agents are accomplished in treating a wide range of depressive disorders especially associated with atypical features such as hypersomnia, increased appetite and weight gain. Patients being treated with MAOls should avoid food containing tyramine due to the risk of developing a hypertensive crisis. MAOls should not be administered less than 5 weeks after the discontinuation of fluoxetine or less than 2 weeks for other SSRIs in order to prevent the occurrence of Serotonin Syndrome. Similarly, SSRIs should not be prescribed within 2 weeks after suspending MAOI treatment. ${ }^{33}$

\section{Serotonin-noradrenaline reuptake inhibitors (SNRIs)}

Venlafaxine, desvenlafaxine and duloxetine can be used as first-line agents in the treatment of depression. These drugs are vigorous selective inhibitors of the presynaptic reuptake of serotonin and noradrenaline, thereby allowing treatment of a wider range of symptoms. SNRIs have no effect on histaminic, a-adrenergic or dopaminergic receptors. They are useful in patients with additional anxiety disorders (OCD, ADHD), significant fatigue (menopausal symptoms) or pain syndromes 
(neuropathic pain, fibromyalgia) associated with depression. ${ }^{34}$ SNRIs are used as second-line treatment in individuals not responding to SSRIs. The concurrent use of SNRIs with other antidepressants or patients with major eating disorders is not recommended..$^{35}$ The safety, tolerability, and side-effect profiles of SNRIs are similar to SSRIs, however treatment initiation requires a low dose which should be gradually increased until symptom improvement is noticed. Abrupt withdrawal causing the "discontinuation syndrome" is more pronounced with SNRIs compared to SSRIs.

\section{Dopamine reuptake inhibitors (DRIs)}

The use of selective DRIs in depression is limited due to their high abuse potential resulting from an increased dopamine concentration and dopaminergic neurotransmission in the brain. Bupropion is currently the only DRI registered for the management of MDD in South Africa. It is preferable over SSRIs because of a decreased likelihood in causing sexual dysfunction, weight gain and gastrointestinal side effects. ${ }^{36}$ Adverse effects include dry mouth, vision disturbances, changes in appetite, tinnitus, confusion and seizures. Sustained release preparations are more tolerable. Bupropion is contraindicated in patients with epileptic disorders.

\section{Tetracyclic antidepressants}

Tetracyclic antidepressants are closely related to the tricyclic antidepressants, only differing in their chemical ring structure. They are multi-potent receptor blockers and act by increasing central noradrenergic and serotonergic neurotransmission. The pharmacological effect is achieved by blocking $5-\mathrm{HT} 1,5-\mathrm{HT} 2$, 5-HT3, alpha2-, and histamine (H1) receptors. Sedation and weight gain are the main adverse effects but tend to improve over time. Severe cardiotoxicity has led to most of these agents being withdrawn from the market. The use of tetracyclic antidepressants has largely been replaced by newer agents with fewer side effects.

\section{Serotonin receptor antagonists and reuptake inhibitors (SARIS)}

Trazodone acts predominantly as a 5-HT2A receptor antagonist and therefore has similar properties to the SSRIs. In addition, it is an antagonist of $\mathrm{H} 1$ and alpha1 adrenergic receptors. Lower doses of trazodone required to be an effective antidepressant are needed to cause sedation, and is therefore rather used in the management of insomnia than for its antidepressant effects. ${ }^{37}$

\section{Selective Noradrenaline Re-Uptake inhibitors (NTIs)}

Reboxetine selectively inhibits noradrenaline reuptake into the presynaptic neurons. It is a low risk antidepressant compared to the DRIs, and is useful in depressed patients with marked apathy, cognitive slowing or psychomotor retardation. Side effects include insomnia, sweating, tachycardia, weight loss, dry mouth and changes in blood pressure. ${ }^{38}$

\section{Multimodal antidepressants}

Vortioxetine is the latest agent used in the management of MDD. It is classified as a serotonin modulator and stimulator. Although the mechanism of action is not yet fully understood, it enhances serotonergic activity in the CNS through the inhibition of reuptake of serotonin by 5-HT3 antagonist and 5-HT1A agonist. It displays a more favorable side effect profile, less weight gain, less sexual dysfunction and superior compliance compared to SSRIs, SNRIs and agomelatine. Vortioxetine is safe for use in the elderly. The most common adverse effects include nausea, headache and diarrhea. ${ }^{39}$

\section{Melatonergic agonists}

Agomelatine has a unique mechanism of action, not shared by any of the known antidepressants. It has no effect on monoamine uptake, and has no affinity for adrenergic, histaminergic, cholinergic or dopaminergic receptors. Agomelatine is an agonist on MT1 and MT2 receptors, and an antagonist on $5-\mathrm{HT} 2 \mathrm{C}$ receptors in the frontal cortex. It therefore increases noradrenaline and dopamine release directly and resynchronises circadian rhythms. Additional indications include treatment of anxiety disorders, bipolar depression and obsessive-compulsive disorder. Side effects are rare and include sweating, gastrointestinal disturbances, headache, anxiety, dizziness and raised liver enzymes. A few case reports have indicated $0.1 \%$ of patients experiencing mania, suicidal ideation, hallucinations and liver failure. ${ }^{40} \mathrm{It}$ is contraindicated in liver and kidney impairment and acts as a substrate of CYP1A2, CYP2C9 and $\mathrm{CYP} 2 \mathrm{C} 19$. Agomelatine should not be used in children under 18 years since there is still a lack of safety data.

\section{Herbal remedies (eg. St. John's wort)}

St. John's wort (Hypericum perforatum) is a herbal remedy available over the counter. The exact mechanism of action is not known but studies suggest it may act as an SSRI. It is only used in the management of mild to moderate depressive symptoms, and is not recommended as a first-line treatment modality. St John's wort lacks the adverse effects on sexual function and is not associated with any anticholinergic side effects. ${ }^{41}$ Potentially serious drug interactions with protease inhibitors, NNRTIs and cycloserine have been described as a result of CYP3A4 enzyme induction. ${ }^{42}$

\section{Treatment-resistant depression}

Up to two thirds of depressed patients fail to respond on firstline therapy. Presently, no variables have been identified to reliably predict if an individual will respond or not. ${ }^{43}$ Patients presenting with treatment-resistant depression should be assessed on the accuracy of diagnosis, presence of comorbid conditions (eg. substance abuse, anxiety disorders, personality disorders), adequacy of medication dose, duration of treatment, and adherence to the treatment regimen. Possible interventions may include increasing the dose to the maximum tolerated amount, augmenting the current medication with another antidepressant, changing to a different antidepressant, or initiating psychotherapy if not already done. If a desirable response is still not observed after 4-6 weeks, it could be considered to combine the current antidepressant with another antidepressant from a different class and mechanism of action. Alternatively, augmentation strategies such as the addition of lithium, or an atypical antipsychotic may be investigated. ${ }^{44}$ 
Table I. Available agents in the management of depression in South Africa

\begin{tabular}{|c|c|c|c|c|c|}
\hline Active Ingredient & Trade name & Strength & $\begin{array}{l}\text { SEP per } \\
\text { original } \\
\text { packaging }\end{array}$ & Dosage & Comments \\
\hline \multicolumn{6}{|c|}{ Selective serotonin reuptake inhibitors (SSRIs) } \\
\hline \multirow{10}{*}{ Citalopram } & Arrow Citalopram ${ }^{\circledast}$ & $\begin{array}{l}20 \mathrm{mg} \\
40 \mathrm{mg}\end{array}$ & $\begin{array}{l}\text { R73.29 (30) } \\
\text { R106.40 (30) }\end{array}$ & \multirow{10}{*}{$\begin{array}{l}\text { Start at } 20 \mathrm{mg} \text {. } \\
\text { Increase by } 20 \mathrm{mg} / \mathrm{d} \\
\text { for } 1-2 \text { weeks until } \\
\text { desired response is } \\
\text { reached. } \\
\text { Max } 40 \mathrm{mg} / \mathrm{d}\end{array}$} & \multirow{10}{*}{$\begin{array}{l}\text { Additional indication in obsessive- } \\
\text { compulsive disorder and panic disorder } \\
\text { Off-label use for generalized anxiety } \\
\text { disorder and premenstrual dysphoric } \\
\text { disorder } \\
\text { Second line alternative in paediatric } \\
\text { patients not responsive to fluoxetine or } \\
\text { sertraline } \\
\text { Least likely SSRI to cause weight gain } \\
\text { Least likely SSRI associated with erectile } \\
\text { impairment, but may cause anorgasmia } \\
\text { May cause QT prolongation at doses } \geq \\
40 \text { mg } \\
\text { Second least likely SSRI to cause drug } \\
\text { interactions (inhibits CYP1A2+, CYP2D6+) }\end{array}$} \\
\hline & Austell Citalopram ${ }^{\oplus}$ & $\begin{array}{l}10 \mathrm{mg} \\
20 \mathrm{mg} \\
40 \mathrm{mg}\end{array}$ & $\begin{array}{l}\text { R52.41 (30) } \\
\text { R75.77 (30) } \\
\text { R116.65 (30) }\end{array}$ & & \\
\hline & Bio Citalopram ${ }^{\circledast}$ & $20 \mathrm{mg}$ & R14.33 (30) & & \\
\hline & Cilate $^{\circledR}$ & $20 \mathrm{mg}$ & $\mathrm{R} 75.84(30)$ & & \\
\hline & Cilift $^{\circledR}$ & $20 \mathrm{mg}$ & R87.62 (30) & & \\
\hline & Ciloram $^{\circledR}$ & $20 \mathrm{mg}$ & R79.54 (30) & & \\
\hline & Cipramil $^{\circledR}$ & $20 \mathrm{mg}$ & R315.12 (28) & & \\
\hline & Depramil $^{\circledR}$ & $\begin{array}{l}20 \mathrm{mg} \\
40 \mathrm{mg}\end{array}$ & $\begin{array}{l}\text { R82.95 (30) } \\
\text { R118.40 (30) }\end{array}$ & & \\
\hline & Recita $^{\circledR}$ & $20 \mathrm{mg}$ & R77.93 (30) & & \\
\hline & Talomil $^{\circledR}$ & $20 \mathrm{mg}$ & $\mathrm{R} 67.26(30)$ & & \\
\hline \multirow{11}{*}{ Escitalopram } & Accord Escitalopram ${ }^{\circledR}$ & $\begin{array}{l}10 \mathrm{mg} \\
20 \mathrm{mg}\end{array}$ & $\begin{array}{l}\text { R57.68 (28) } \\
\text { R80.38 (28) }\end{array}$ & \multirow{11}{*}{$\begin{array}{l}\text { Start at } 10 \mathrm{mg} / \mathrm{d} \text { and } \\
\text { increase to } 20 \mathrm{mg} / \mathrm{d}\end{array}$} & \multirow{5}{*}{$\begin{array}{l}\text { Additional indication in obsessive- } \\
\text { compulsive disorder, panic disorder, social } \\
\text { anxiety disorder, generalized anxiety } \\
\text { disorder }\end{array}$} \\
\hline & Aspen Escitalopram ${ }^{\circledR}$ & $10 \mathrm{mg}$ & $\mathrm{R} 157.73(30)$ & & \\
\hline & Cipralex $^{\circledR}$ & $\begin{array}{l}10 \mathrm{mg} \\
20 \mathrm{mg}\end{array}$ & $\begin{array}{l}\text { R258.25 (28) } \\
\text { R484.99 (28) }\end{array}$ & & \\
\hline & Citraz $^{\mathbb{R}}$ & $\begin{array}{l}10 \mathrm{mg} \\
20 \mathrm{mg}\end{array}$ & $\begin{array}{l}\text { R88.06 (30) } \\
\text { R176.13 (30) }\end{array}$ & & \\
\hline & Dolin $^{\circledR}$ & $\begin{array}{l}10 \mathrm{mg} \\
20 \mathrm{mg}\end{array}$ & $\begin{array}{l}\text { R92.27 (30) } \\
\text { R105.79 (30) }\end{array}$ & & \\
\hline & $\begin{array}{l}\text { Escitalopram } \\
\text { Winthrop }^{\circledR}\end{array}$ & $\begin{array}{l}5 \mathrm{mg} \\
10 \mathrm{mg} \\
20 \mathrm{mg}\end{array}$ & $\begin{array}{l}\text { R77.66 (30) } \\
\text { R89.60 (30) } \\
\text { R119.47 (30) }\end{array}$ & & \multirow{2}{*}{$\begin{array}{l}\text { Off-label use for premenstrual dysphoric } \\
\text { disorder, fibromyalgia, posttraumatic } \\
\text { stress disorder, Raynaud phenomenon } \\
\text { Not licensed in South Africa for the use in } \\
\text { paediatric patients }\end{array}$} \\
\hline & Lexamil $^{\circledR}$ & $\begin{array}{l}5 \mathrm{mg} \\
10 \mathrm{mg} \\
20 \mathrm{mg}\end{array}$ & $\begin{array}{l}\text { R84.18 (30) } \\
\text { R84.18 (30) } \\
\text { R165.25 (30) }\end{array}$ & & \\
\hline & Marprem ${ }^{\circledast}$ & $\begin{array}{l}5 \mathrm{mg} \\
10 \mathrm{mg} \\
20 \mathrm{mg}\end{array}$ & $\begin{array}{l}\text { R88.35 (30) } \\
R 77.03(30) \\
R 70.42(30)\end{array}$ & & \multirow[t]{4}{*}{$\begin{array}{l}\text { Least likely SSRI to cause drug } \\
\text { interactions (inhibits CYP2D6+) }\end{array}$} \\
\hline & Mylan Escitalopram ${ }^{\circledR}$ & $\begin{array}{l}10 \mathrm{mg} \\
20 \mathrm{mg}\end{array}$ & $\begin{array}{l}\text { R92.60 (28) } \\
\text { R185.20 (30) }\end{array}$ & & \\
\hline & Zitolex $^{\circledR}$ & $\begin{array}{l}10 \mathrm{mg} \\
20 \mathrm{mg}\end{array}$ & $\begin{array}{l}\text { R43.00 (28) } \\
\text { R65.70 (28) }\end{array}$ & & \\
\hline & Zytomil $^{\circledR}$ & $\begin{array}{l}10 \mathrm{mg} \\
20 \mathrm{mg}\end{array}$ & $\begin{array}{l}\text { R88.20 (30) } \\
\text { R113.81(30) }\end{array}$ & & \\
\hline \multirow{9}{*}{ Fluoxetine } & Deprozan $^{\circledR}$ & $20 \mathrm{mg}$ & $\mathrm{R} 23.80(30)$ & \multirow{9}{*}{$\begin{array}{l}\text { Start at } 10 \mathrm{mg} / \mathrm{d} \text { and } \\
\text { increase to } \\
20 \mathrm{mg} / \mathrm{d} \text { if necessary. } \\
\text { Max } 60 \mathrm{mg} / \mathrm{d} \text {. }\end{array}$} & Additional indication in bulimia nervosa \\
\hline & Fluoxetine Actor $20^{\circledR}$ & $20 \mathrm{mg}$ & $\mathrm{R} 28.01(30)$ & & \multirow{3}{*}{$\begin{array}{l}\text { Off label use for obsessive-compulsive } \\
\text { disorder, panic disorder, social anxiety } \\
\text { disorder, generalized anxiety disorder, } \\
\text { impulse control disorder, personality } \\
\text { disorders }\end{array}$} \\
\hline & Lilly-Fluoxetine ${ }^{\oplus}$ & $20 \mathrm{mg}$ & R137.11 (28) & & \\
\hline & $\begin{array}{l}\text { Lorien }^{\circledR} \text { Tab } \\
\text { Lorien }^{\circledR} \text { Cap }\end{array}$ & $20 \mathrm{mg}$ & $\begin{array}{l}\text { R84.43 (30) } \\
\text { R41.56 (28) }\end{array}$ & & \\
\hline & Nuzak $^{\circledR}$ & $20 \mathrm{mg}$ & R46.05 (30) & & $\begin{array}{l}\text { First line treatment in paediatric and } \\
\text { adolescent patients }\end{array}$ \\
\hline & $\begin{array}{l}\text { ProHexal }^{\circledR} \mathrm{C} \\
\text { Prohexal }^{\circledR} \mathrm{T} \\
\text { Prohexal }^{\circledR} \mathrm{T}\end{array}$ & $\begin{array}{l}20 \mathrm{mg} \\
20 \mathrm{mg} \\
40 \mathrm{mg}\end{array}$ & $\begin{array}{l}\text { R44.32 (30) } \\
\text { R87.75 (30) } \\
\text { R175.57 (30) }\end{array}$ & & $\begin{array}{l}\text { May cause initial weight loss (1st month), } \\
\text { thereafter weight gain }\end{array}$ \\
\hline & $\begin{array}{l}\operatorname{Prozac}^{\oplus} \mathrm{C} \\
\text { Prozac }^{\oplus} \mathrm{T}\end{array}$ & $\begin{array}{l}20 \mathrm{mg} \\
20 \mathrm{mg}\end{array}$ & $\begin{array}{l}\text { R343.22 (30) } \\
\text { R343.22 (30) }\end{array}$ & & $\begin{array}{l}\text { Increase awakenings and reduce REM } \\
\text { sleep }\end{array}$ \\
\hline & Ranflocs $^{\circledR}$ & $20 \mathrm{mg}$ & R28.14 (30) & & \multirow{2}{*}{$\begin{array}{l}\text { Second most likely SSRI to cause } \\
\text { drug interactions (Inhibits CYP1A2+, } \\
\text { CYP2C9++, CYP2C19++, CYP2D6+++, } \\
\text { YP3A4+, CYP2B6+) }\end{array}$} \\
\hline & Sandoz-Fluoxetine & $20 \mathrm{mg}$ & $\mathrm{R} 41.28(30)$ & & \\
\hline
\end{tabular}




Luvox $^{\mathbb{R}} \quad$ 100mg R407.31(30)

\section{Fluvoxamine}

Faverin $^{\circledR} \quad 100 \mathrm{mg} \quad$ R278.53 (30)

Start at $50 \mathrm{mg} / \mathrm{d}$, may increase to

$150 \mathrm{mg} / \mathrm{d}$ after a week if tolerated
Additional indication for obsessivecompulsive disorder

Off-label use in anxiety disorder, posttraumatic stress disorder, pain disorder

Not licensed in South Africa for paediatric use

High incidence of withdrawal symptoms

Highest incidence of Gl side effects

First most likely SSRI to cause drug interactions (Inhibits CYP1A2+++, CYP2C9++, CYP2C19+++, CYP2D6+, CYP3A4+, CYP2B6+

Additional indication in obsessivecompulsive disorder, panic disorder, social anxiety disorder, generalized anxiety disorder

Third most likely SSRI to cause drug interactions (inhibits CYP1A2+, CYP2C9+, CYP2C19+, CYP2D6+++, CYP3A4+, CYP2B6+++)

Start at $20 \mathrm{mg} / \mathrm{d}$

\begin{tabular}{|lll} 
Deparoc $^{\circledR}$ & $20 \mathrm{mg}$ & $\mathrm{R} 177.70(28)$ \\
Lenio $^{\circledR}$ & $20 \mathrm{mg}$ & $\mathrm{R} 149.02(30)$ \\
Paxil $^{\circledR}$ & $20 \mathrm{mg}$ & $\mathrm{R} 203.38(28)$
\end{tabular}

Increase by $10 \mathrm{mg}$ increments according Increase awakenings and reduce REM

Paroxetine

\begin{tabular}{|lll}
\hline Paxil $^{\circledR}$ & $20 \mathrm{mg}$ & R203.38 (28) \\
\hline Paroxetine Unicorn $^{\circledR}$ & $20 \mathrm{mg}$ & $\mathrm{R} 159.83(30)$ \\
\hline Serapress $^{\circledR}$ & $20 \mathrm{mg}$ & R148.87 (30) \\
\hline Texine $^{\circledR}$ & $20 \mathrm{mg}$ & $\mathrm{R} 149.02(30)$ \\
XET 20 $^{\circledR}$ & $20 \mathrm{mg}$ & $\mathrm{R} 121.54(30)$ \\
\end{tabular}

to response.

Max $50 \mathrm{mg} / \mathrm{d}$ sleep

Most likely to cause sexual dysfunction in males and females

Higher incidence of withdrawal symptoms due to short half life Contraindicated in pregnancy. Avoid in pediatric use.

\begin{tabular}{|c|c|c|c|}
\hline \multirow{9}{*}{ Sertraline } & Aspen Sertraline ${ }^{\circledR}$ & $50 \mathrm{mg}, 100 \mathrm{mg}$ & $\mathrm{N} / \mathrm{A}$ \\
\hline & Austell Sertraline ${ }^{\circledR}$ & $\begin{array}{c}50 \mathrm{mg} \\
100 \mathrm{mg}\end{array}$ & $\begin{array}{l}\text { R131.27 (30) } \\
\text { R185.32 (30) }\end{array}$ \\
\hline & Dyna Sertraline ${ }^{\circledR}$ & $\begin{array}{c}50 \mathrm{mg} \\
100 \mathrm{mg}\end{array}$ & $\begin{array}{l}R 73.80(30) \\
R 78.60(30)\end{array}$ \\
\hline & Serdep ${ }^{\circledR}$ & $\begin{array}{c}50 \mathrm{mg} \\
100 \mathrm{mg}\end{array}$ & $\begin{array}{l}\text { R87.39 (30) } \\
\text { R107.84 (30) }\end{array}$ \\
\hline & Serlife ${ }^{\circledR}$ & $\begin{array}{c}50 \mathrm{mg} \\
100 \mathrm{mg}\end{array}$ & $\begin{array}{l}\text { R82.58 (30) } \\
R 165.17(30)\end{array}$ \\
\hline & Sertra ${ }^{\circledR}$ & $50 \mathrm{mg}$ & $\mathrm{R} 136.23(30)$ \\
\hline & Sertraline Winthrop ${ }^{\circledR}$ & $50 \mathrm{mg}$ & R135.96 (30) \\
\hline & Zolid $^{\circledR}$ & $\begin{array}{c}50 \mathrm{mg} \\
100 \mathrm{mg}\end{array}$ & $\begin{array}{l}\text { R88.03 (30) } \\
\text { R108.47 (30) }\end{array}$ \\
\hline & Zoloft $^{\circledR}$ & $50 \mathrm{mg}$ & R356.60 (30) \\
\hline \multicolumn{4}{|c|}{ Tricyclic antidepress } \\
\hline \multirow[b]{3}{*}{ Amitriptyline } & Trepiline $^{\circledR}$ & $\begin{array}{l}10 \mathrm{mg} \\
25 \mathrm{mg}\end{array}$ & $\begin{array}{l}\text { R96.02 (100) } \\
\text { R98.03 (100) }\end{array}$ \\
\hline & $\begin{array}{l}\text { Sandoz } \\
\text { Amitriptyline }\end{array}$ & $25 \mathrm{mg}$ & $\mathrm{R} 67.72(100)$ \\
\hline & & & \\
\hline \multirow{3}{*}{ Imipramine } & Tofranil $^{\circledR}$ & $\begin{array}{l}10 \mathrm{mg} \\
25 \mathrm{mg}\end{array}$ & $\begin{array}{l}\text { R193.33 (100) } \\
\text { R349.07 (100) }\end{array}$ \\
\hline & & $10 \mathrm{mg}$ & R46.48 (100) \\
\hline & Ethipramine ${ }^{\circledR}$ & $25 \mathrm{mg}$ & R54.85 (100) \\
\hline
\end{tabular}

Start at $50 \mathrm{mg} / \mathrm{d}$, may increase to $200 \mathrm{mg} / \mathrm{d}$ after a week if tolerated

Additional indication in obsessivecompulsive disorder, panic disorder

Off-label use in social anxiety disorder, generalized anxiety disorder, posttraumatic stress disorder

Reduces nocturnal wakefulness

Highest incidence of insomnia Fourth most likely SSRI to cause drug interactions (inhibits CYP1A2+, CYP2C9+, CYP2C19+, CYP2D6+, CYP3A4+, CYP2B6+)

Alternative to fluoxetine in paediatric use
Initial dose of $25 \mathrm{mg}$ at bedtime Increase in $25 \mathrm{mg}$ increments every 3-7 days to $150 \mathrm{mg} /$ day
Additional indication in anxiety disorders and nocturnal enuresis in children over 11 years of age

Used off-label for chronic pain management, diabetic neuropathy, migraine prophylaxis, and posttraumatic stress disorder.

Due to sedating effect useful in patients with insomnia.

ECG monitoring is recommended

Initial dose of $10 \mathrm{mg}$. Increase in $25 \mathrm{mg}$ increments every 3-7 days to max $100 \mathrm{mg} /$ day
Additional indication in anxiety disorders, nocturnal enuresis in paediatric patients over 5 years of age. 


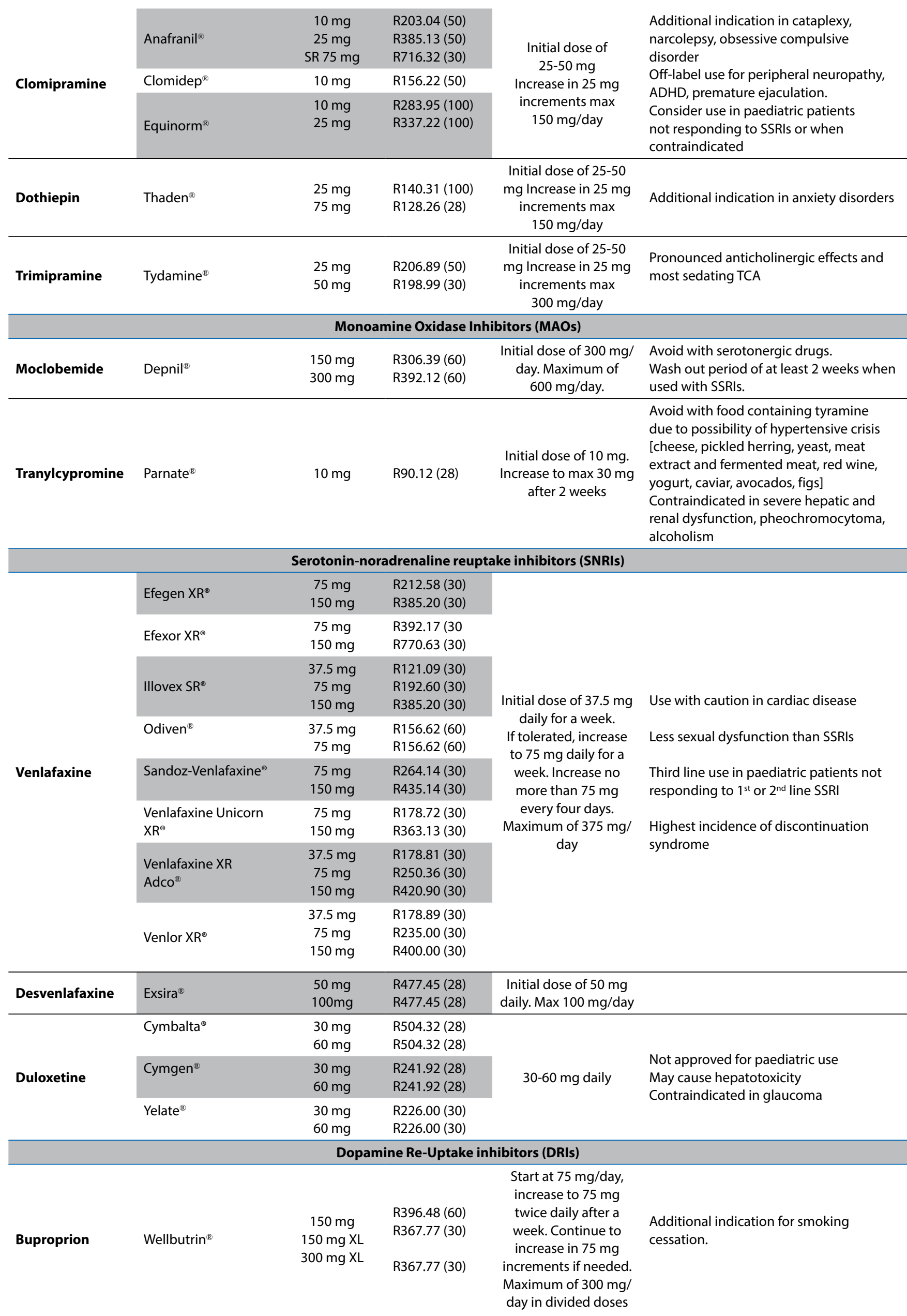




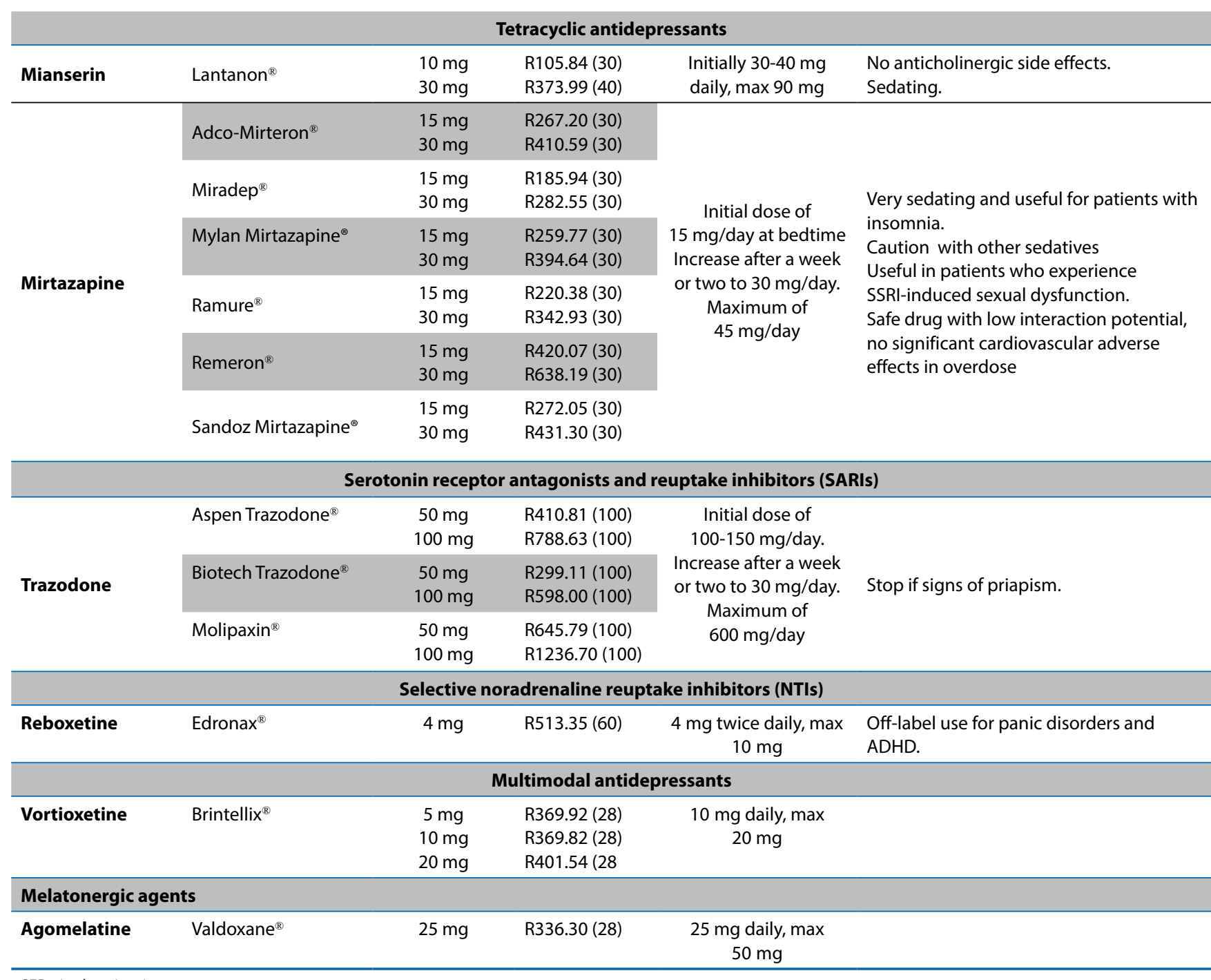

SEP: single exit price

* Single exit price as listed in the Monthly Index of Medical Specialities. 2016;56(10)

\section{Paediatric depression treatment}

Fluoxetine is the only agent currently approved in South Africa for the treatment of depression in children. SSRIs may induce mania, hypomania, agitation, sleep disturbances and appetite changes in paediatric patients. The health care practitioner therefore needs to council parents or care givers about the adverse effects, safe storage, proper administration, risk of suicide and danger of overdose before initiating pharmacological treatment. TCAs are not considered to be first-line treatment for paediatric patients with depressive disorders, but may be useful in those with comorbid attention deficit hyperactivity disorder (ADHD), enuresis, and narcolepsy. Prior to initiating treatment with a TCA, baseline electrocardiogram (ECG), resting blood pressure, and pulse rate should be determined. Weight and plasma levels should frequently be monitored to avoid toxicity and ensure compliance. $^{45}$

\section{Depression during pregnancy and postpartum depression}

Although avoiding the use of medication during pregnancy is preferable, the benefits of prompt medical treatment of major depressive disorder may often outweigh the risks of exposure of the fetus to an antidepressant. Conflicting evidence exists regarding the use of SSRIs during pregnancy and an increased risk of persistent pulmonary hypertension of the newborn. Some rare birth defects have been observed with the use of specific SSRIs, however no clear evidence indicates that available antidepressants are teratogenic. ${ }^{46,47}$ The same risk-benefit considerations should be applied as when treating postpartum depression. For first episodes of depression in postpartum women, 6-12 months of treatment is recommended. Recurrent major depression requires long-term antidepressant treatment. ${ }^{48}$

\section{Antidepressants and breastfeeding}

Most antidepressants are likely to be safe for use during breastfeeding. However, studies on the use of antidepressants during lactation have not been adequately evaluated. The same risk-benefit considerations should be applied as when managing depression during pregnancy. ${ }^{49}$

\section{Antidepressants and the elderly}

Elderly patients respond to antidepressant agents more slowly, they have a higher incidence of side effects and more drugdrug interactions due to polypharmacy. Antidepressant therapy should be initiated at a lower dose ( $50 \%$ of the normal dose) and slowly titrated until the desired therapeutic effect is achieved. 
Elderly patients taking SSRIs may develop clinically significant hyponatremia, including an increased risk of stroke and suicide. Abrupt discontinuation of SSRIs with shorter half-lives, such as paroxetine, may induce withdrawal symptoms which could be confused with recurrence of a depressive episode. Paroxetine discontinuation may additionally cause cholinergic rebound, manifesting with symptoms affecting the gastrointestinal tract. Should nausea and weight loss persist, it is recommended that other treatment options be explored..$^{50}$

\section{Conclusion}

A wide range of effective treatment is available for major depressive disorder. The choice of medication should be guided by a careful assessment of symptoms, patient comorbid psychiatric or general medical conditions, contraindications as well as an analysis of therapeutic benefits and side effects, potential drug interactions and cost. Psychoactive substance abuse and suicide risk should be carefully assessed. Appropriate and up-to-date pharmacological knowledge is necessary in the successful management of depressive episodes.

For a clinical response to become evident, it is necessary to continue treatment for 2-12 weeks at a therapeutic dose. Treatment for major depressive disorder should be re-evaluated if the patient does not have an adequate pharmacotherapeutic response within 6-8 weeks. SSRIs or SNRIs should be considered as first-line treatment for mild to moderate depression. All SSRIs require a wash-out period of at least two weeks before starting other SSRIs, MAOIs or TCAs. SSRIs should not be prescribed within 2 weeks after discontinuation of MAOI therapy. The possibility of SSRI drug interactions are the highest with fluoxetine, paroxetine, and fluvoxamine and the lowest with escitalopram, citalopram, and sertraline. TCAs are used less frequently as a result of their unfavorable anticholinergic and cardiovascular side-effect profile, attenuated by their considerable toxicity in overdose. TCAs, trazodone, mianserin, mirtazapine and agomelatine are useful in depressed patients with insomnia. Venlafaxine, bupropion, mirtazapine, agomelatine and vortioxetine are less likely to cause sexual dysfunction than SSRIs. The combination of an antidepressant with an antipsychotic is recommended in severe major depression with psychotic features. In the case of a relapse, the antidepressant dosage should be increased, or treatment with another first-line agent with a different mechanism of action should be considered.

\section{References}

1. World Health Organization. Depression [Internet]. 2016 [updated April 2016; cited 10 December 2016]. Fact sheet No 369:Available from: http://www.who.int/ mediacentre/factsheets/fs369/en/.

2. Angst J, Preisig M. Course of a clinical cohort of unipolar, bipolar and schizoaffective patients. Results of a prospective study from 1959 to 1985. Schweizer Archiv fur Neurologie und Psychiatrie 1995;146:5-16.

3. Wells KB, Hays RD, Burnam MA, et al. Detection of depressive disorder for patients receiving prepaid or fee-for service care. Results from the Medical Outcomes Study. Jama.1989;262:3298-302.

4. Kessler RC, Berglund P, Demler O. The epidemiology of major depressive disorder: results from the National Comorbidity Survey Replication (NCS-R). Jama. 2003;289(23):3095-105.
5. Andersson LM, Schierenbeck I, Strumpher J, et al. Help-seeking behaviour, barriers to care and experiences of care among persons with depression in Eastern Cape, South Africa. J Affect Disord. 2013;151(2):439-48.

6. Freeman $\mathrm{CP}$, Joska JA. Dealing with major depression. S Afr Pharm J. 2013;80:16-21.

7. Paykel ES. Epidemiology of refractory depression. In: Nolen WA, Zohar J, Roose SP, Amsterdam JD, eds. Refractory Depression: Current Sstrategies and Future Directions. Chichester: Wiley,1994;3-17.

8. Petersen I, Lund C. Mental health service delivery in South Africa from 2000 to 2010: one step forward, one step back. S Afr Med J. 2011;101(10):751-7.

9. Hasler G. Pathophysiology of depression: do we have any solid evidence of interest to clinicians? World Psychiatry. 2010;9(3):155-61.

10. Elkin I, Shea MT, Watkins JT, et al. National Institute of Mental Health Treatment of Depression Collaborative Research Program. General effectiveness of treatments. Arch Gen Psychiatry. 1989;46(11):971-82; discussion 983.

11. Sullivan PF, Neale MC, Kendler KS. Genetic epidemiology of major depression: review and meta-analysis. Am J Psychiatry. 2000;157(10):1552-62.

12. Sheline $\mathrm{Yl}, \mathrm{Gado} M \mathrm{MH}$, Kraemer HC. Untreated depression and hippocampal volume loss. Am J Psychiatry. 2003;160(8):1516-18.

13. Kendler KS, Gardner CO, Prescott CA. Toward a comprehensive developmental model for major depression in men. Am J Psychiatry. 2006;163(1):115-24.

14. Kendler KS, Gardner CO, Prescott CA. Toward a comprehensive developmental model for major depression in women. Am J Psychiatry. 2002;159(7):1133-45.

15. Frodl TS, Koutsouleris N, Bottlender $R$, et al. Depression-related variation in brain morphology over 3 years: effects of stress? Arch Gen Psychiatry. 2008;65(10):1156-65.

16. Heim C, Newport DJ, Mletzko T, Miller AH, Nemeroff CB. The link between childhood trauma and depression: insights from HPA axis studies in humans. Psychoneuroendocrinology. 2008;33(6):693-710.

17. Young EA. Sex differences and the HPA axis: implications for psychiatric disease. J Gend Specif Med. 1998;1(1):21-7.

18. Nemeroff CB, Widerlov E, Bissette G, et al. Elevated concentrations of CSF corticotropin-releasing factor-like immunoreactivity in depressed patients. Science. 1984;226(4680):1342-4.

19. Schatzberg AF, Lindley S. Glucocorticoid antagonists in neuropsychiatric [corrected] disorders. Eur J Pharmacol. 2008;583(2-3):358-64.

20. Dantzer R, O'Connor JC, Freund GG, Johnson RW, Kelley KW. From inflammation to sickness and depression: when the immune system subjugates the brain. Nat Rev Neurosci. 2008;9(1):46-56.

21. Belmaker RH, Agam G. Major depressive disorder. $N$ Engl J Med. 2008;358(1):55-68.

22. Nemeroff CB. The corticotropin-releasing factor (CRF) hypothesis of depression: new findings and new directions. Mol Psychiatry. 1996;1(4):336-42.

23. Meyer JH, Ginovart N, Boovariwala A, et al. Elevated monoamine oxidase a levels in the brain: an explanation for the monoamine imbalance of major depression. Arch Gen Psychiatry. 2006;63(11):1209-16.

24. Zhang X, Gainetdinov RR, Beaulieu JM, et al. Loss-of-function mutation in tryptophan hydroxylase-2 identified in unipolar major depression. Neuron. 2005;45(1):11-16.

25. Hasler G, van der Veen JW, Tumonis T, et al. Reduced prefrontal glutamate/ glutamine and gamma-aminobutyric acid levels in major depression determined using proton magnetic resonance spectroscopy. Arch Gen Psychiatry. 2007;64(2):193-200.

26. Eser D, Schule C, Baghai TC, Romeo E, Rupprecht R. Neuroactive steroids in depression and anxiety disorders: clinical studies. Neuroendocrinol. 2006;84(4):244-54.

27. Montgomery SA, Asberg M. A new depression scale designed to be sensitive to change. Br J Psychiatry. 1979;134:382-9.

28. Montgomery SA, Judge R. Treatment of depression with associated anxiety: comparisons of tricyclic antidepressants and selective serotonin reuptake inhibitors. Acta Psychiatr Scand Suppl. 2000;403:9-16.

29. Practice guideline for the treatment of patients with major depressive disorder (revision). American Psychiatric Association. Am J Psychiatry. 2000;157(4 Suppl):1-45.

30. Ferguson JM. SSRI Antidepressant Medications: Adverse Effects and Tolerability. Prim Care Companion J Clin Psychiatry. 2001;3(1):22-7.

31. Davidson JR. Major depressive disorder treatment guidelines in America and Europe. J Clin Psychiatry. 2010;71 Suppl E1:e04. 
32. Anderson IM, Nutt DJ, Deakin JF. Evidence-based guidelines for treating depressive disorders with antidepressants: a revision of the 1993 British Association for Psychopharmacology guidelines. British Association for Psychopharmacology. J Psychopharmacol. 2000;14(1):3-20.

33. Hilton SE, Maradit $\mathrm{H}$, Moller HJ. Serotonin syndrome and drug combinations: Focus on MAOI and RIMA. Eur Arch Psychiatry Clin Neurosci. 1997;247(3):113-9.

34. Bourin M, David DJP, Jolliet $P$, Gardier A. Mechanism of action of antidepressants and therapeutic perspectives. Therapie. 2002;57(4):385-96.

35. Nutt DJ, Davidson JR, Gelenberg AJ, et al. International consensus statement on major depressive disorder. J Clin Psychiatry. 2010;71 Suppl E1:e08.

36. Walker PW, Cole JO, Gardner EA, et al. Improvement in fluoxetine associated sexual dysfunction in patients switched to bupropion. J Clin Psychiatry. 1993;54(12):459-65.

37. Royal Australian and New Zealand College of Psychiatrists, Clinical Practice Guidelines Team for Depression. Australian and New Zealand Clinical Practice Guidelines for the Treatment of Depression. Aust N Z J Psychiatry. 2004;38(6):389-407.

38. Caudill MM, Hunter AM, Cook IA, Leuchter AF. The Antidepressant Treatment Response Index as a Predictor of Reboxetine Treatment Outcome in Major Depressive Disorder. Clin EEG Neurosci. 2015;46(4):277-84.

39. Katona $\mathrm{CL}$, Katona CP. New generation multi-modal antidepressants: focus on vortioxetine for major depressive disorder. Neuropsychiatr Dis Treat. 2014;10:349-54.
40. Emet M, Ozcan H, Ozel L, et al. A Review of Melatonin, Its Receptors and Drugs. Eurasian J Med. 2016;48(2):135-41.

41. Lecrubier Y, Clerc G, Didi R, Kieser M. Efficacy of St. John's wort extract WS 5570 in major depression: a double-blind, placebo-controlled trial. Am J Psychiatry. 2002;159(8):1361-6.

42. Effect of Hypericum perforatum (St John's wort) in major depressive disorder: a randomized controlled trial. Jama. 2002;287(14):1807-14.

43. Geddes J, Butler R. Depressive disorders. Clin Evid. 2002(8):951-73.

44. Fava M, Rush AJ. Current status of augmentation and combination treatments for major depressive disorder: a literature review and a proposal for a novel approach to improve practice. Psychother Psychosom. 2006;75(3):139-53.

45. Hammad TA, Laughren T, Racoosin J. Suicidality in pediatric patients treated with antidepressant drugs. Arch Gen Psychiatry. 2006;63(3):332-9.

46. Kalra S, Born L, Sarkar M, Einarson A. The safety of antidepressant use in pregnancy. Expert Opin Drug Saf. 2005;4(2):273-84.

47. Eberhard-Gran M, Eskild A, Opjordsmoen S. Treating mood disorders during pregnancy: safety considerations. Drug Saf. 2005;28(8):695-706.

48. Wisner KL, Parry BL, Piontek CM. Clinical practice. Postpartum depression. N Engl J Med. 2002;347(3):194-9.

49. Kohen D. Psychotropic medication and breast-feeding. Adv Psychiatr Treat. 2005;11:371-9.

50. Baldwin R, Wild R. Management of depression in later life. Adv Psychiatr Treat. 2004;10:131-9. 